\title{
Corporate diversification and firms' value in emerging economy: the role of growth opportunity
}

\author{
Rahmat Heru Setianto \\ Department of Management, Universitas Airlangga, Surabaya, Indonesia
}

\begin{abstract}
Purpose - This paper examines empirically how growth opportunities determine the relationship between corporate diversification and firm's value in an emerging economy.

Design/methodology/approach - This study employs annual data of Indonesian manufacturing firm's spanning five years. To test the potential nonlinear relationship between diversification and value, nonlinear regression model is employed. Baron and Kenny's (1986) procedure is also employed to test the mediation role of the growth opportunities in the relation between diversification strategy and firm's value. This study also performs further robustness analysis on mediating role of growth opportunities on the relationship between diversification strategy and corporate value using path analysis approach.

Findings - The analyses reveal the U-shaped diversification and value relationship; this result suggests that the effect of diversification on value will vary across firms, the negative effect of diversification strategy on firm's value may reverse at higher levels of diversification. Further analysis indicates that such relationship is fully mediated by firm's growth opportunities.

Practical implications - Given the results, firms that are considering implementing diversification strategy should seek the optimal level of diversification to gain diversification premium. Furthermore, the manager should observe the best opportunities available for the firm before undertaking the diversification strategies.

Originality/value - This paper contributes to the existing literature on diversification strategy by extending the insight of this research area of a large emerging economy, on which prior studies have not reached conclusive results.
\end{abstract}

Keywords Diversification, Firm's value, Growth opportunities, Emerging economy

Paper type Research paper

\section{Introduction}

The main goal of diversification strategy employed by a company is to increase performance as well as revenue from its new product. However, its effect on a firm value remains largely a controversy in the literature. Over the years, there has been a large body of empirical research concerning on this issue. Research on testing the implications of diversification for value creation has produced unoptimistic impact of diversification on creating value of the firm. For instance, Lang and Stulz (1994); Berger and Ofek (1995); Comment and Jarell (1995); Denis et al. (1997); Desai and Jain (1999); Stowe and Xing (2006); Hoechle et al. (2012) depict a negative effect of diversification on value, diversification discount. In contrast, other studies report the diversification premium (e.g., Palich et al., 2000; Campa and Kedia, 2002; Lamont and Polk, 2001; Villalonga, 2004a; Miller, 2004; Santalo and Becera, 2008; Kuppuswamy and

(C) Rahmat Heru Setianto. Published in Journal of Asian Business and Economic Studies. Published by Emerald Publishing Limited. This article is published under the Creative Commons Attribution (CC BY 4.0) licence. Anyone may reproduce, distribute, translate and create derivative works of this article (for both commercial and non-commercial purposes), subject to full attribution to the original publication and authors. The full terms of this licence may be seen at: http://creativecommons.org/licences/by/4.0/ legalcode

We would like to thank Dr. Su Dinh Thanh (the editor), the associate editor, anonymous referee, the Department of Management Universitas Airlangga, All errors are the responsibility of the author.
Corporate diversification and firms' value

Received 22 August 2019 Revised 22 October 2019 2 March 2020

Accepted 6 March 2020

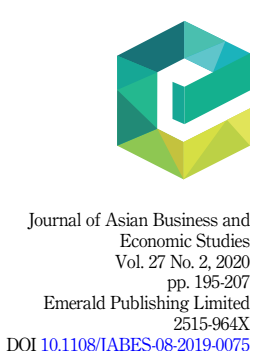

DOI 10.1108/JABES-08-2019-0075 
JABES

27,2

196

Villalonga, 2016), while some other studies find insignificant relationship between diversification and value (Villalonga, 2004b; Elsas et al., 2010).

Unclear prediction resulted from the theoretical work on the relation between diversification and firms' value and motivates further studies on the factors that affect this relationship puzzle, since the existing theoretical paradigm cannot provide a satisfactory answer to this question. Some researchers (Campa and Kedia, 2002; Miller, 2004; Villalonga, 2004; Hoechle et al., 2012) suggest that some endogeneity factors may affect the diversification and performance relationship. Thus researchers must carefully look at the company's characteristic prior to diversification so that the effect on the value of diversification can be observed more precisely. However, after controlling for several endogeneity factors, the results are still inconclusive. Campa and Kedia (2002) indicate that diversification has positive effect on firms' value. While Hoechle et al. (2012) still find negative results even with accommodating several endogenous factors. In this sense, current literatures offer some contingent approach to examine the unclear impact of diversification on firm's value across firms. Andres et al. (2014) review factors that potentially influenced this relationship, namely the institutional framework as argued by Lins and Servaes (1999), the industry as argued by Santalo and Becera (2008) and diversity growth opportunities (Rajan et al., 2000).

Among these factors, growth opportunity is a factor that has been studied by several literatures, but the results are still mixed, such as research conducted by Ferris et al. (2002), which finds that diversification will destroy the value of the companies with low growth opportunities. While Bernado and Chowdhry (2002) also indicate similar results, where firms with multiple segments experienced lower growth opportunities than single-segment companies. Furthermore, Stowe and Xing (2006) also find a negative impact of diversification on firm value even by controlling for difference level of growth opportunities between diversified and undiversified firms.

The diversification and value relationship has been widely examined in the context of developed market, but limited empirical studies are available from emerging market. In the case of emerging market, a few studies examined some endogeneity that may influence the impact of diversification on corporate value. For instance, Lien and Li (2013); Lee et al. (2012); Chen and $\mathrm{Yu}$ (2012) and Bertin et al. (2015) investigate the role of ownership structure and corporate governance in explaining the relationship, with inconclusive results, and need further research in understanding the relationship between diversification and firm value in an emerging economy.

Considering the theoretical and practical significance, the inconclusive evidence of the relationship between diversification strategy and firm value and the role of endogeneity factor in determining such relationships motivate us to have a fresh look at the issues of diversification strategies in the context of emerging economies, namely Indonesia. Indonesia is potentially interesting case study for developing economies, which shares most of the characteristics of a typical emerging market. Home country environment may impose a tremendous effect on the diversification strategy used by the firm as well as diversification performance resulted from the strategy (Xiarong, 2007). Indonesian economy experienced significant growth during the last decade, along with the other three countries with the highest economic growth, namely China, India and Brazil. Currently, Indonesia is the world's fourth most populous nation, the world's tenth largest economy in terms of purchasing power parity, the largest economy in Southeast Asia and a member of the G-20. Such condition encourages the emergence of enterprise group in Indonesia. Indonesia has been becoming a more significant player in the global economy, especially in the South East Asian region.

Moreover, as compared to capital market in the advanced economies, Indonesian stock markets are less developed. As argued by Gertner et al. (1994) and Lee et al. (2012), the firms in emerging economies may rely more on the internal capital markets as well as bank as a financing source because of its underdeveloped stock market. Therefore, companies in 
developing markets will enjoy more benefits from diversification strategy (Lee et al., 2012). The aforementioned characteristics may not apply in the case of developed economy where most of previous studies have conducted. Therefore, this study is expected to fill the gap as well as expand our insight on the diversification-value relationship in the context of emerging economy.

Inspired by the current business practices in Indonesia as well as the remaining diversification puzzle, this study attempted to expand the empirical examination on the relationship between firm diversification and value into Indonesia's economy. This study focus is to investigate the impact of diversification strategy on firm value in Indonesia. Furthermore, this research also empirically investigates whether the impact of diversification strategy on firm value may be contingent on growth opportunities. For this purpose, we employ causal step method developed by Baron and Kenny (1986). This method has been adopted by Andres et al. (2014) for the US data. But we have extended the analysis by adopting Sobel test approach developed by Sobel (1988), which is superior to Baron and Kenny's (1986) method (in terms of power, Type I error, suppression effects and addressing the significance of the indirect effect) in examining the direct and indirect effect of diversification strategy on firm's value.

This paper contributes to the existing literature on diversification strategy by extending the insight of this research area of a large emerging economy, on which prior studies have not reached conclusive results. We documented the empirical results of U-shape relationship between diversification and growth opportunity as well as firm value. Additionally, we further establish the fact that this nonlinear relationship is fully mediated by growth opportunities, suggesting the significant role of growth opportunities in determining the value of the firm in relation to corporate diversification.

The rest of the paper is organized as follows: the next section provides a review of relevant literature. Section 3 describes the data and sample characteristics. Section 4 discusses the details of empirical model and variables. Section 5 reports the main empirical results. Section 6 contains a summary of the main findings and concluding remarks.

\section{Literature review}

The relationship between diversification strategy and firm performance has been empirically evaluated by previous research for the case of developed and emerging economies. They can be classified based on their evidence, which range from diversification discount [1] (negative relationship) as the major position to the diversification premium [2] (positive relationship).

Lang and Stulz (1994) examine diversification and value relationship during the 1980s and find a negative impact of diversification on firm value, the result is robust for different measurement as well as after controlled by other determinant of firm value. Meanwhile, Berger and Ofek (1995) find interesting results, they conclude that the value loss from diversification comes from overinvestment and cross-subsidization. Moreover, Servaes (1996) investigates the impact of diversification on value during the 1960s and 1970s. The results reveal large discount during the 1960s, but the discount declined to zero during the 1970s. Stowe and Xing (2006) assess the diversification discount on diversified and singlesegment firms by employing 230 diversifying firms from 1981 to 1997. They find significant valuation discount in diversified firms even when they control for difference in growth opportunity between diversified and undiversified firms. More recently, Hoechle et al. (2012) investigated whether the diversification discount occurs partly as an artifact of poor corporate governance. In panel data models, the results reveal that governance variables weaken the negative impact of diversification on value destruction.

While the aforementioned studies documented the diversification discount, the depressed value on diversified firms does not mean that diversification strategy resulted in value destruction. As study by Campa and Kedia (2002) revealed, the impact of diversification on 
JABES 27,2

198

value is negative and sometimes turns into a premium. The evidence pointed out on the importance of considering potential endogeneity factors that may determine the diversification strategy and value relationship. Vilalonga (2004a) provides supportive evidence of diversification premium by measuring the diversification strategy based on business unit instead of segments.

Among these conflicting results, there are several theoretical arguments that may explain the difference results on diversification-value relationship. Among others, Rumelts (1982) and Shelton (1988) argue that the decision to diversify might be an important consideration in planning for corporate growth and expansion. This argument is supported by evidence provided by Hyland and Diltz (2002), which find that diversifying firms have lower growth opportunity than undiversified firms before the diversification is applied. Hence, firms choose diversification strategy due to the low growth opportunities in their current industry (Stowe and Xing, 2006). Furthermore, according to Bernanrdo and Chowdhry (2002), the choice to implement the diversification strategy might result in less growth opportunity than average single-segment firm; hence, they should have lower value relative to the industry average. Thus, difference in growth opportunity level might explain the difference impact of diversification on value across firms.

As argued by Myers (1977), there are at least two elements that comprised of firm value, namely the value of assets in place and the value of future growth opportunities. Empirical research conducted by Danbolt et al. (2002) indicates that the present value of growth opportunity on average contributes more than $50 \%$ of market value of the firms. Hence, growth opportunity has dominant portion in creating total firm value than the other component (asset in place).

Previous studies considered growth opportunity in their analysis on the effect of diversification-value relationship (Berger and Ofek, 1995; Mansi and Reeb, 2002; Denis et al., 2002) by controlling cross-sectional difference in growth opportunities among firms. According to Stowe and Xing (2006), this control might not be sufficient because when we examine the diversification and value relationship, the most important factor is the gap in level of growth opportunities of the diversified firm segments and its benchmarks rather than the variation among the firms. Stowe and Xing (2006) then address this issue by developing a model that considers the difference in the level of growth between diversified firm and its undiversified benchmarks industry. However, the evidence of diversification discount remains even after controlling for growth opportunities. This means that growth opportunities cannot explain the diversification discount phenomena.

These literature strands leave open the question of whether the impact of diversification on value may be contingent on growth opportunities. We seek to fill this gap by employing a different approach in examining the role of growth opportunity on the relation between diversification strategy and firms' value. As growth opportunities are the major component of firm's value, and the purpose of diversification is to gain higher growth rate, this study will examine whether the effect of diversification on firm's value is channeled via growth opportunities. To test the potential mediating role of growth opportunity on the diversification and value relationship, we adopt Baron and Kenny's (1986) causal step approach. According to this approach, if direct effect of diversification strategy on firm's value as widely documented in previous study became weaker once the growth opportunities are incorporated in the model, it will confirm that the diversification-value relationship is channeled through growth opportunity.

\section{Data and sample characteristic}

To examine the role of growth opportunity on relationship between diversification strategy and firm value, data from public listed firms of the manufacturing sector of 
Indonesia Stock Exchange spanning from 2014 to 2018 are employed. The selected firms are firms that provide information about industry segment data at the four-digit SIC code level in their financial report, based on the number 5 of Indonesian accounting standard. Most of the data were retrieved from the listed companies' financial report posted on the Indonesia Stock Exchange (IDX) website. Next, the firms with negative equity and outliers are excluded from the sample. Final samples comprise of 270 firm-years observation of Indonesian manufacturing firms by referring to the aforementioned criteria.

\section{Empirical model and variables}

Following Andres et al. (2014) to examine whether the growth opportunity plays as a channel on the relation between diversification strategy and firm's value, in the first step we will employ the following model, Equation (1):

$$
\begin{aligned}
\mathrm{GOR}_{i t}= & \alpha+\beta_{1} \mathrm{DIVER}_{i t}+\beta_{2} \mathrm{DTA}_{i t}+\beta_{3} \mathrm{Size}_{i t}+\beta_{4} \mathrm{firm}_{-} \text {dummies } \\
& +\beta_{5} \text { year_dummies }_{i t}+v_{i t}
\end{aligned}
$$

Where GOR is the growth opportunity ratio measured by Tobin's $Q$ (Cao et al., 2008). The degree of diversification is computed using Herfindahl index (HERF) and total entropy as alternative measurement. Herfindahl index (HERF) as developed by Hirschman (1964) is calculated as:

$$
\mathrm{HERF}=1-\sum_{s=1}^{n} P_{s}^{2}
$$

where " $n$ " is the number of a firm's segments at the four-digit SIC code level and " $P$ " is the proportion of the firm's sales from segment " $s$ ". The value of HERF ranges between 0 and 1 , the value of 0 indicating the focused firm and 1 indicating the fully diversified firm. To calculate total entropy (ENTROPY), we follow the technique developed by Jacquemin and Berry (1979) as follows:

$$
\text { Entropy }=\sum_{s=1}^{n} P_{S} \times \ln \left[\frac{1}{P_{S}}\right]
$$

where " $n$ " represents the number of a firm's segments at the four-digit SIC code level and " $P$ " is the proportion of the firm's sales from segment " $s$ ". The higher the index, the greater the diversification.

We add control variables in the model, namely firm size (Size) measured by the natural logarithm of the total assets, leverage (DTA) estimated using ratio of total debt to total asset. We also control for firm and year effect, respectively.

Once we find significant relation between diversification and growth opportunity, then we will employ the model developed by Baron and Kenny (1986) to test the mediation role of the growth opportunities in the relation between diversification strategy and firm's value. Baron and Kenny (1986) and Andres et al. (2014) argue that a variable will be considered as a mediator if it meets the following conditions: (1) variations in the independent variable (the level of diversification, in Eqn 1) significantly account for the variation in the growth opportunity as presumed mediator. (2) Variation in the growth opportunity significantly accounts for variation in the excess value. (3) When these two variables (growth opportunity and level of diversification) are put together in one model, a previously significant relation between dependent and independent variables is no longer significant (full mediation) or
Corporate diversification and firms' value 
JABES

27,2 becomes weaker (partial mediation). The conditions (1) and (2) will be tested using the following Equations (2)-(4).

$$
\begin{aligned}
\text { ExcessValue }_{i t}= & \alpha+\beta_{1} \text { DIVER }_{i t}+\beta_{2} \text { EBIT_S }_{i t}+\beta_{3} \text { CAPEX_S }_{i t}+\beta_{4} \text { LDTA }_{i t}+\beta_{5} \text { Size }_{i t} \\
& +\beta_{6} \text { firm_dummies }_{i t}+\beta_{7} \text { year_dummies }_{i t}+v_{i t}
\end{aligned}
$$

\section{0}

$$
\begin{aligned}
\text { ExcessValue }_{i t}= & \alpha+\beta_{1} \mathrm{GOR}_{i t}+\beta_{1} \mathrm{DIVER}_{i t}+\beta_{2} \mathrm{DIVER}_{i t}^{2}+\beta_{3} \mathrm{EBIT}_{-} S_{i t}+\beta_{4} \mathrm{CAPEX}_{-} S_{i t} \\
& +\beta_{5} \mathrm{LDTA}_{i t}+\beta_{6} \mathrm{Size}_{i t}+\beta_{7} \text { firm_dummies }_{i t}+\beta_{8} \text { year_dummies }_{i t}+v_{i t}
\end{aligned}
$$

The dependent variable is excess value, the natural logarithm of firm's market value to its imputed value if each of its segments operated as a single segment firm [3].

$$
\text { ExcessValue }=\log \left[\frac{\text { MarketVaule }}{\text { ImputedValue }}\right]
$$

Where the market value is the total market value equity and book value of debt, while the firm's imputed value is the sum of its imputed segment values, measured by the following equation:

$$
\text { Imputed Value }=\sum_{t=1}^{n}\left(\text { Segment Sales } \times \gamma_{k}\right)
$$

Segment Sales is the sales of each segment, while $\gamma_{k}$ is the ratio of median market value to sales from all single industry firms in the same industry. In sum, this variable measures the diversification discount/premium by comparing the diversified firm's value against the value of an equivalent portfolio of single-segment firms. We employ this approach to be consistent with Berger and Ofek (1995); Stowe and Xiang (2006) and Andres et al. (2014) to keep the results comparable. Furthermore, similar to other researchers (Berger and Ofek, 1995; Campa and Kedia, 2002; Andres et al., 2014), we control the model for firm profitability measured by EBIT divided by net sales (EBIT_S), level of current investment measured by capital expenditure divided by net sales (CAPEX_S), financial leverage by long-term debt to total assets (LTDA) and firm size as measured by the natural logarithm of total assets (size).

To account for the potential endogeneity problem that might arise because observed relationships between dependent variables and firm-specific characteristics as independent variables reflect not only the effect of independent variables on dependent variables but also the effect of dependent variables on independent variables, we therefore estimated our models using generalized method of moments (GMM) estimator developed by Arellano and Bond (1991).

\section{Empirical findings}

\subsection{Descriptive statistics}

The descriptive statistics of the variables being studied are presented in Table 1 . The average excess value is 1.983 suggesting that most of the firms in the sample are valued at a premium. The firm diversification as measured by Herfindahl as well as entropy index has an average 


\begin{tabular}{|c|c|c|c|c|c|}
\hline & Minimum & Maximum & Mean & Std. Deviation & Corporate \\
\hline Excess value & 0.040 & 13.06 & 1.983 & 2.023 & and firms' \\
\hline HERF & 0.000 & 0.751 & 0.391 & 0.219 & C11 \\
\hline Entropy & 0.000 & 1.655 & 0.649 & 0.388 & value \\
\hline GOR & 0.404 & 27.718 & 2.029 & 2.444 & \\
\hline $\begin{array}{l}\text { Control variables } \\
\text { EBITsales }\end{array}$ & -0.734 & 0.420 & 0,094 & 0117 & 201 \\
\hline CAPEXsales & -1.494 & 0.938 & 0.035 & 0.153 & \\
\hline LDTA & 0.001 & 0.741 & 0.141 & 0.131 & \\
\hline Size & 11.342 & 20.431 & 14.427 & 1.771 & the variables 2014 \\
\hline \multicolumn{5}{|c|}{ Source(s): Authors' calculations } & $2018(N$ \\
\hline
\end{tabular}

value of 0.391 and 0.649 , respectively. Growth opportunity as measured by Tobin's $Q$ ratio has mean value of 2.029 indicating that the majority of the firms being studied valued by investors above their book value of assets, the higher Tobin's $\mathrm{Q}$, the higher the expectations from investors about the firm's potential growth. Finally, control variables, namely EBIT to sales ratio as measure for profitability, current investment (CAPEX to sales ratio), leverage (long-term debt to assets) and firm size (ln total assets) have mean value of 0.094, 0.035, 0.141, 14.427, respectively.

\subsection{The effect of diversification level on growth opportunity}

Table 2 presents the test results on how the levels of diversification, measured by either Herfindahl index or total entropy, affect the growth opportunity. In the first specification, the model used Herfindahl index as diversification measurement, and the results reveal that the relationship between diversification and growth opportunity follows a U-shape. This

\begin{tabular}{lcc}
\hline & \multicolumn{2}{c}{ Dependent variables: growth opportunity $(Q)$} \\
& 1 & 2 \\
\hline Constant & $-1.365^{* *}(0.020)$ & $-3.983^{* * *}(0.001)$ \\
Diversification indexes & & \\
HERF & $-1.869(0.109)$ & \\
HERF2 & $3.001^{*}(0.060)$ & $-1.998(0.107)$ \\
Total entropy & & $1.750^{* *}(0.046)$ \\
Total entropy2 & & \\
Control variables & & $0.423^{* * *}(0.000)$ \\
SIZE & $0.236^{* * *}(0.000)$ & $-2.808^{* *}(0.012)$ \\
LDTA & $-1.118^{* *}(0.036)$ & 270 \\
Number of Obs & 270 & 0.096 \\
Adjusted $R$ square & 0.143 & 0.287 \\
Sargan test: $p$-value & 0.317 & 0.321 \\
$M 2: p$-value & 0.345 & 2.140 \\
Durbin-Watson & 1.981 &
\end{tabular}

Note(s): Figures in parentheses are probability values based on White robust standard errors for heteroskedasticity. *,**,*** denote statistically significance at 1,5 and $10 \%$ level, respectively. $m_{2}$ is a serial correlation test of second-order using residuals of first differences, asymptotically distributed as $N(0,1)$ under null hypothesis of no serial correlation. Sargan test is a test of overidentifying restrictions distributed asymptotically under null hypothesis of validity of instruments as Chi-squared

Table 2. Diversification and growth opportunity [estimated based on Equation 1] 
JABES 27,2

202

nonlinear relationship is statistically significant at $10 \%$ significance level. To check the robustness of the results, we perform the regression based on other approximation, total entropy index, as diversification measurement, as presented in specification 2, and the results reveal that the relationship between total entropy and GOR takes a U-shape and is statistically significant at $5 \%$. This result is supportive of the previous measurement. Having established the significance impact of diversification on growth opportunity, for the next step, Baron and Kenny's (1986) approach is applied to further investigate the possible mediation role of growth opportunity on the diversification strategy and value relationship.

\subsection{The diversification level and firm's value}

In this step, the examination focused on the direct effect of diversification on value of the firms based on Eqns (2) and (3). As shown in Table 3, specifications 1 and 2 estimate the liner impact of diversification on firm's value. The results reveal that there is a negative impact of diversification level on firm's value. This result is consistent with the previous results (Lang and Stulz, 1994; Berger and Ofek, 1995; Comment and Jarel, 1995; Servaes, 1996; Desai and Jain, 1999; and Andres et al., 2014) that find a diversification discount. Furthermore, we also perform test to examine the possible presence of a nonlinear impact of diversification level on firm's value. As presented in specification (3) and (4) of Table 3, the results indicate that the relationship between firm diversification and value follows a U-shape and is statistically significant at the 5\% level of significance. The results are also consistent for both measurement approaches, Herfindahl and total entropy.

Figure 1 provides a plot of nonlinear regression between diversification level and excess value. As shown in the figure, the low level of diversified firm is valued at a discount as compared to undiversified company until minimum point is reached. However, after reaching the critical point, the relationship may change, and it may be possible to gain a diversification premium.

\begin{tabular}{lcccc}
\hline & \multicolumn{4}{c}{ Dependent variables: excess value } \\
& 1 & 2 & 3 & 4 \\
\hline Constant & $-0.678^{*}(0.077)$ & $-0.536(0.158)$ & $-0.419(0.286)$ & $-0.296(0.462)$ \\
Diversification indexes & & & \\
HERF & $0.538^{* *}(0.010)$ & & $-1.282^{*}(0.096)$ & \\
HERF2 & & & $2.585^{* *}(0.015)$ & \\
Total entropy & & $0.242^{* *}(0.042)$ & & $-0.404(0.304)$ \\
Total entropy2 & & & & $0.482^{*}(0.085)$ \\
Control variables & & & & \\
EBIT_S & $0.937^{* *}(0.030)$ & $1.025^{* *}(0.018)$ & $0.992^{* *}(0.021)$ & $1.084^{* *}(0.012)$ \\
CAPEX_S & $-0.728^{* *}(0.026)$ & $-0.727^{* *}(0.028)$ & $-0.741^{* *}(0.023)$ & $-0.725^{* *}(0.027)$ \\
LDTA & $-0.967^{* * *}(0.006)$ & $-0.953^{* * *}(0.008)$ & $-0.860^{* *}(0.015)$ & $-0.926^{* * *}(0.009)$ \\
Size & $0.037(0.163)$ & $0.030(0.263)$ & $0.031(0.241)$ & $0.023(0.402)$ \\
Number of Obs & 270 & 270 & 270 & 270 \\
Adjusted $R$ square & 0.075 & 0.066 & 0.094 & 0.073 \\
Sargan test: $p$-value & 0.321 & 0.341 & 0.352 & 0.335 \\
M2: $p$-value & 0.354 & 0.286 & 0.305 & 0.281 \\
Durbin-Watson & 1.915 & 1.925 & 1.945 & 1.977 \\
Note(s): rigurs & in & &
\end{tabular}

Table 3.

Diversification and

Note(s): Figures in parentheses are probability values based on White robust standard errors for heteroskedasticity. $* * * * * * *$ denote statistically significance at 1,5 and $10 \%$ level, respectively. $m_{2}$ is a serial correlation test of second-order using residuals of first differences, asymptotically distributed as $N(0,1)$ under null hypothesis of no serial correlation. Sargan test is a test of overidentifying restrictions distributed based on Eqns 2 and 3] asymptotically under null hypothesis of validity of instruments as Chi-squared 
5.4 The mediation role of growth opportunities in the relationship between diversification and firm's value

Having established the significant U-shaped relationship between diversification and excess value, for the next step, we apply Baron and Kenny's (1986) approach to further investigate the mediation role of growth opportunity on the relation between diversification and firm's value. According to Baron and Kenny (1986), if growth opportunity plays as mediator, a previously significant impact of diversification on excess value will no longer be significant or becomes weaker when growth opportunity is considered in the regression model.

We report the estimation results of Equation (4) in Table 4. Specifications (1) and (2) reveal the presence of a significant relationship between growth opportunities $(Q)$ and excess value. In line with previous research (Ferris et al. (2002); Andres et al., 2014) but opposed to Stowe and Xing (2006), the results suggest that the higher the growth opportunities, the greater the premium.

Furthermore, our results reveal evidence of supporting full mediation role of growth opportunity. As shown in Table 4, when growth opportunity (GOR) is included in the model, the coefficients associated with the quadratic term of diversification lost their statistically significant. These results suggest that a growth opportunity is fully mediating the U-shape relationship between diversification and excess value, suggesting the essential role of growth opportunities in determining this relationship.

\subsection{The robustness analysis}

We perform further robustness analysis on mediating role of growth opportunities on the relationship between diversification strategy and corporate value. For this purpose, we employ path analysis approach developed by Wright (1934). This approach enables us to examine multiple direct and indirect effects of a dependent variable. Diagram presented in Figure 2 provides the test results on how the diversification and value relationship is affected by growth opportunity that acts as mediating variable.

The results reveal that diversification has significant direct effect on firm value as well as indirect effect through growth opportunity as mediating variable. The magnitude coefficient of direct relationship between diversification and value is 0.631 as shown on the path line 1 (p1) with probability value ( $p$-value) of 0.029 . While the magnitude coefficient of indirect effect through growth opportunity as mediating variable is 0.2615 , this value is obtained by multiplying the coefficient of path line $2(0.835)$ and coefficient of path line $3(0.317)$. Sobel (1988) test results provide the t-statistic of 2.060908 , which is greater than its critical value (1.96), suggesting that this indirect relationship is statistically significant. In general, the
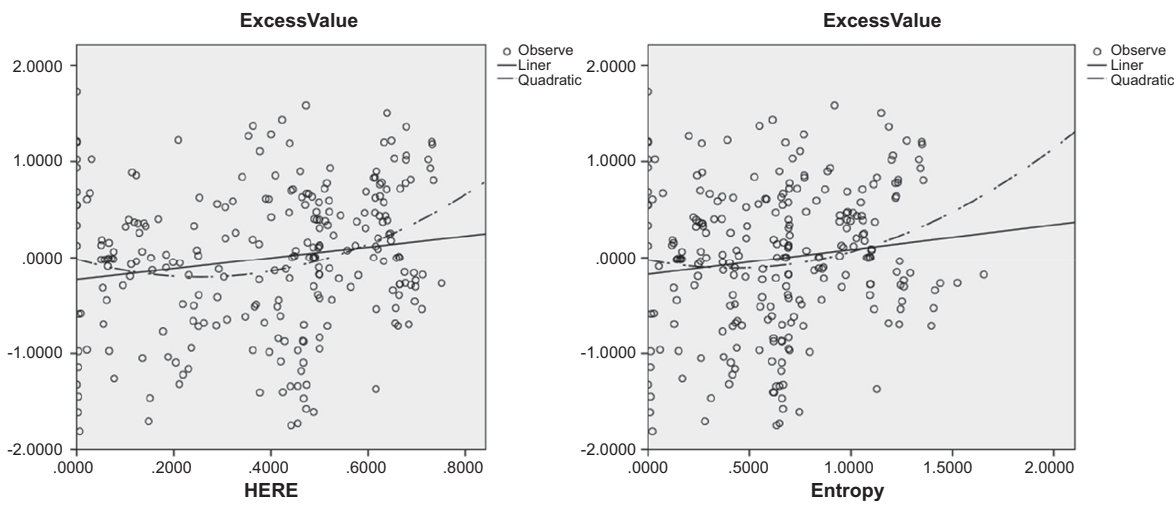

Corporate diversification and firms' value

203
Figure 1.

Plot of nonlinear relationship between diversification (Herfindahl and total entropy index) and excess value 


\section{JABES}

27,2

\begin{tabular}{l}
204 \\
\hline Table 4. \\
Regression analysis of \\
the mediating role of \\
growth opportunity on \\
the diversification- \\
value relationship \\
[estimated based on \\
Eqn 4]
\end{tabular}

Figure 2.

Path analysis model

\begin{tabular}{lcc}
\hline & \multicolumn{2}{c}{ Dependent variables: excess value } \\
& 1 & 2 \\
\hline Constant & $-2.885^{* * *}(0.001)$ & $-3.222^{* * *}(0.000)$ \\
GOR $(Q)$ & $0.214^{* * *}(0.000)$ & $0.206^{* * *}(0.000)$ \\
Diversification indexes & & \\
HERF & $-0.347(0.838)$ & \\
HERF2 & $-1.319(0.567)$ & $-0.411(0.632)$ \\
Total entropy & & $-0.314(0.605)$ \\
Total entropy2 & & \\
Control variables & & $5.998^{* * *}(0.000)$ \\
EBIT_S & $6.173^{* * *}(0.000)$ & $-1.611^{* *}(0.023)$ \\
CAPEX_S & $-1.629^{* *}(0.022)$ & $-0.966(0.216)$ \\
LDTA & $-0.956(0.225)$ & $0.337^{* * * *}(0.000)$ \\
Size & $0.308^{* * *}(0.000)$ & 270 \\
Number of Obs & 270 & 0.376 \\
Adjusted $R$ square & 0.370 & 0.304 \\
Sargan test: $p$-value & 0.265 & 0.285 \\
$M 2: p$-value & 0.258 & 1.597 \\
Durbin-Watson & 1.598 &
\end{tabular}

Note(s): Figures in parentheses are probability values based on White robust standard errors for heteroscedasticity.*, $* *, * * *$ denote statistically significance at 1,5 and $10 \%$ levels, respectively. $m_{2}$ is a serial correlation test of second-order using residuals of first differences, asymptotically distributed as $N(0,1)$ under null hypothesis of no serial correlation. Sargan test is a test of overidentifying restrictions distributed asymptotically under null hypothesis of validity of instruments as Chi-squared

results from path analysis are consistent with the results from three steps of regression analysis as discussed in the previous section.

\section{Conclusion}

This study is attempted to provide an examination of the widely inconclusive impact of firm diversification on firm's value for the case of an emerging economy. We undertake this study in an emerging market environment by employing data from Indonesian public listed manufacturing companies. This paper is trying to identify endogeneity factor, namely growth opportunities that may obscure the true relationship between diversification and value. We adopt Baron and Kenny's (1986) approach to examine the possible mediation role of growth opportunities by applying three sequential regression test procedures. 
In the first step of regression analysis, we documented the significant U-shaped relationship between diversification level and growth opportunities. The results indicate that in the low levels of diversification, companies may suffer the declining growth opportunity due to some adaptation that needed in managing new product or business line. While in the latter stages, diversifications converted as key source of further growth strategy. This result may be due to the progressive accumulation of experience, knowledge and capabilities of the organization obtained from simultaneously taking part in some businesses, which expands a firm's capacity to sense and seize opportunities in a broader range of industries. This argument has been proposed by Andres et al. (2014), who found the same results in their study on US firms.

In the second step of analysis, we documented the U-shape relationship between diversification and firm's excess value. The finding suggests, at early stages of diversification, the benefit gained from diversification is less than the cost yielding a wealth discount. Beyond the critical level, the marginal benefits of diversification exceed the cost yielding diversification premiums.

In the last part of the analysis, this study documented empirical evidence for the mediating role of growth opportunity on the relationship between diversification and value. Growth opportunity plays an important role concerning the value of the diversification levels. This result is consistent with previous findings reported for US firms (Ferris et al. (2002); Andres et al., 2014), who find that the wealth impact of corporate diversification strategy is not absolute, but it is conditional upon the firm's resources and growth opportunities.

The findings of this study provide several interesting implications for firms and investors. Given evidence of $U$-shaped relationship between diversification and growth opportunities as well as relationship between diversification and value, firms that are considering implementing diversification strategy should seek the optimal level of diversification to gain diversification premium. Furthermore, due to the significant role of growth opportunity in determining the effectiveness of this strategy, the manager should observe the best opportunities available for the firm before undertaking the diversification strategies. For prospective investors, they need to carefully examine the growth opportunity available before making the decision to invest in diversified firm.

A limitation of this study is that the related analysis mainly focused on the role of growth opportunity as mediator on the diversification-value relationship. This analysis did not consider the effect of other endogeneity factors that may explain this relationship. The authors would like to call for further study on this interesting issue, especially in the context of emerging market, by considering other possible factors that might provide a deeper insight into the circumstances under which this strategy is implemented more effectively by the firms.

\section{Notes}

1. For example, studies conducted by: Lang and Stulz (1994); Berger and Ofek (1995); Servaes (1996); Stowe and Xing (2006); Hoechle et al. (2012)

2. Study by Campa and Kedia (2002) and Vilalonga, (2004a).

3. For the detailed explanation of these variables, see Berger and Ofek (1995)

\section{References}

Andrés, P., Fuente, G. and Velasco, P. (2014), "Growth opportunities and the effect of corporate diversification on value”, The Spanish Review of Financial Economics, Vol. 12 No. 2014, pp. 72-81.

Arellano, M. and Bond, S. (1991), "Some Tests of Specification for Panel Data: Monte Carlo Evidence and an Application to Employment Equations", The Review of Economic Studies, Vol. 58 No. 2, pp. 277-297. 
JABES 27,2

Baron, R. and Kenny, D. (1986), "The moderator-mediator variable distinction in social psychological research: conceptual, strategic and statistical considerations", Journal of Personality and Social Psychology, Vol. 51 No. 26, pp. 1173-1182.

Berger, P.G. and Ofek, E. (1995), "Diversification's effect on firm value", Journal of Financial Economics, Vol. 37 No. 1, pp. 39-65.

Bernardo, A. and Chowdhry, B. (2002), "Resources, real options, and corporate strategy", Journal of Financial Economics, Vol. 63, pp. 211-234.

Bertin, M.J., Iturriaga, F.J.L. and Espinosa (2015), "Diversification and control in emerging markets: the case of Chilean firms", Business Research Quarterly, Vol. 18 No. 2015, pp. 259-274.

Campa, J.M. and Kedia, S. (2002), "Explaining the diversification discount", The Journal of Finance, Vol. 57 No. 4, pp. 1731-1762.

Cao, C., Simin, T. and Zhao, J. (2008), "Can growth options explain the trend in idiosyncratic risk?", The Review of Financial Studies, Vol. 21 No. 6, pp. 2599-2633.

Chen, C.J. and Yu, C.M.J. (2012), "Managerial ownership, diversification, and firm performance: evidence from an emerging market”, International Business Review, Vol. 21 No. 3, pp. 518-534.

Comment, R. and Jarell, G.A. (1995), "Corporate focus and stock returns", Journal of Financial Economics, Vol. 37, pp. 67-87.

Danbolt, J., Hirst, I. and Jones, E. (2002), "Measuring growth opportunities", Applied Financial Economics, Vol. 12, pp. 203-212.

Denis, D., Denis, D.K. and Sarin, A. (1997), "Agency problems, equity ownership and corporate diversification”, Journal of Finance, Vol. 52 No. 1, pp. 135-160.

Denis, D., Denis, D. and Yost, K. (2002), "Global diversification, industrial diversification, and firm value”, Journal of Finance, Vol. 57, pp. 1951-1979.

Desai, H. and Jain, P.C. (1999), "Firm performance and focus: long-run stock market performance following spinoffs", Journal of Financial Economics, Vol. 54, pp. 75-101.

Elsas, R., Hackethal, A. and Holzhäuser, M. (2010), "The anatomy of bank diversification”, Journal of Banking and Finance, Vol. 34 No. 6, pp. 1274-1287.

Ferris, S.P., Sen, N., Lim, C.Y. and Yeo, G.H. (2002), "Corporate focus versus diversification: the role of growth opportunities and cash flow", Journal of International Financial Markets, Institutions and Money, Vol. 12 No. 3, pp. 231-252.

Gertner, R., Scharfstein, D. and Stein, J. (1994), "Internal versus external capital markets”, Quarterly Journal of Economics, Vol. 109, pp. 1211-1230.

Hirschman, A. (1964), "The paternity of an index", American Economic Review, Vol. 54 No. 5, pp. 761-770.

Hoechle, D., Schmid, M., Walter, I. and Yermarck, D. (2012), "How much of the diversification discount can be explained by poor corporate governance?", Journal of Financial Economics, Vol. 103 No. 1, pp. 41-60.

Hyland, D. and Diltz, J., (2002), "Why firms diversify: an empirical examination", Financial Management, Vol. 31, pp. 51- 81.

Jacquemin, A.P. and Berry, C.H. (1979), "Entropy measure of diversification and corporate growth", The Journal of Industrial Economics, Vol. 27 No. 4, pp. 359-369.

Kuppuswamy, V. and Villalonga, B. (2016), "Does diversification create value in the presence of external financing constraints? Evidence from the 2007-2009 financial crisis", Management Science, Vol. 62 No. 4, pp. 905-923.

Lamont, O. and Polk, C. (1999), "The diversification discount: cash flow vs returns", The Journal of Finance, Vol. 56 No. 5, pp. 1693-1721.

Lang, L. and Stulz, R. (1994), “Tobin's Q, corporate diversification and firm performance”, Journal of Political Economy, Vol. 102 No. 6, pp. 1248-1280. 
Lee, K.T., Hooy, C.W. and Hooy, G.K. (2012), "The value impact of international and industrial diversifications on public listed firms in Malaysia”, Emerging Market Review, Vol. 13, pp. 366-380.

Lien, Y.C. and Li, S. (2013), "Does diversification add firm value in emerging economies? Effect of corporate governance", Journal of Business Research, Vol. 66, pp. 2425-2430.

Corporate diversification and firms' value

Mansi, S. and Reeb, D. (2002), “Corporate diversification: what gets discounted?”, Journal of Finance, Vol. 57, pp. 2167- 2183.

Myers, S.C. (1977), "Determinants of corporate borrowing", Journal of Financial Economics, Vol. 5 No. 2, pp. 147-175.

Miller, D.J. (2004), "Firms' technological resources and the performance effects of diversification: a longitudinal study", Strategic Management Journal, Vol. 25 No. 11, pp. 1097-1119.

Palich, L.E., Cardinal, L.B. and Miller, C. (2000), "Curvilinearity in the diversification performance linkage: an examination of over three decades of research", Strategic Management Journal, Vol. 21 No. 2, pp. 155-174.

Rajan, R., Servaes, H. and Zingales, L. (2000), "The cost of diversity: the diversification discount and inefficient investment", The Journal of Finance, Vol. 55 No. 1, pp. 35-80.

Rumelt, R., (1982),"Diversification strategy and profitability”, Strategic Management Journal, Vol. 3, pp. 359-369.

Santaló, J. and Becerra, M. (2008), "Competition from specialized firms and the diversificationperformance linkage", The Journal of Finance, Vol. 63 No. 2, pp. 851-883.

Servaes, H. (1996), "The value of diversification during the conglomerate merger wave", The Journal of Finance, Vol. 51 No. 4, pp. 1201-1225.

Shelton, L. (1988), "Strategic business fits and corporate acquisition: empirical evidence", Strategic Management Journal, Vol. 9, pp. 279-287.

Sobel, M.E. (1988), "Direct and indirect effects in linear structural equation models", Sociological Methods \& Research, Vol. 16 No. 1, pp. 155-176.

Stowe, J.D. and Xing, X. (2006), "Can growth opportunities explain the diversification discount?", Journal of Corporate Finance, Vol. 12 No. 4, pp. 783-796.

Villalonga, B. (2004a), "Diversification discount or premium? New evidence from BITS establishmentlevel data", The Journal of Finance, Vol. 59 No. 2, pp. 479-506.

Villalonga, B. (2004b), "Does diversification cause the 'diversification discount'?", Financial Management, Vol. 33 No. 2, pp. 5-27.

Wright, S. (1934), "The method of path coefficients", Annals of Mathematical Statistics, Vol. 5 No. 3, pp. 161-215.

Xiarong, L. (2007), Diversification and Corporate Performance: Evidence from China, PhD Dissertation, Maastricht School of Management, Maastricht, The Netherlands.

\section{Corresponding author}

Rahmat Heru Setianto can be contacted at: rahmat.heru@feb.unair.ac.id

For instructions on how to order reprints of this article, please visit our website:

www.emeraldgrouppublishing.com/licensing/reprints.htm

Or contact us for further details: permissions@emeraldinsight.com 